\title{
Impact of Changing Microstructural Compositions of Lime Based Mortar on Flexibility: Case Study of Sustainable Lime-Cement Composites
}

\author{
Sule Adeniyi Olaniyan*
}

Department of Architecture, Ladoke Akintola University of Technology, Ogbomoso, 210211, Nigeria

\begin{tabular}{l} 
A R T I C L E I N F O \\
\hline Article history: \\
Received: 02 April, 2020 \\
Accepted: 03 December, 2020 \\
Online: 21 December, 2020 \\
\hline Keywords: \\
Composite \\
Flexibility \\
Modulus of Elasticity \\
Porosity \\
Sustainability
\end{tabular}

\section{Introduction}

Lime mortar, an age-long building material [1], is primarily popular for its flexibility, the basis of its ability to accommodate

${ }^{*}$ Corresponding Author: Sule Adeniyi Olaniyan, Email: saolaniyan@lautech.edu.ng www.astesj.com

\begin{abstract}
A B S T R A C T
Lime mortar, an age-long building material is primarily popular for its flexibility, the basis of its ability to accommodate masonry deformation, hence durability. However, lime's characteristic delayed setting/hardening time, low mechanical strength and poor internal cohesion often characterised by volumetric changes have put its use into decline. These shortcomings have therefore relegated relevance of this fundamental flexibility feature which underscores limes' excellent performance and durability characteristics. The research therefore attempted to leverage this feature through evaluation of synergised lime composites, using cement as a partial replacement for lime. This is with a view to integrating advantageous features of 'lime and cement' as a composite, at the expense of their known individual drawbacks. The methodology involved mortars with the same Binder/Aggregate (B/A) mix ratio (1:3) using five different compositions of 'cement-lime' binders (i.e. 1:1, 1:2, 1:3, 2:1 and 3:1). The research focused on comparative evaluations of each composition in both fresh and hardened states, with the latter covering twelve-month curing period. While Water/Binder ratio constituted the fresh state assessment parameters, mechanical characteristics and microstructural features were evaluated in the hardened state. Results of the investigation show that progressive addition of cement significantly changes pore size distribution (PSD) of lime mortar from predominant pore sizes between $(0.5-5 \mu \mathrm{m})$ and $(5$ $-20 \mu \mathrm{m})$ into $(10 \mathrm{~nm}-2 \mu \mathrm{m})$ range. This alteration is associated with porosity reduction by up to $11 \%$. Significant improvements in the mechanical strengths of the composite is recorded as both the compressive and flexural strengths of the composite with $75 \%$ of cement is 18 and 6 times higher respectively, compared with the reference mortar. However, progressive addition of cement is proportional to the E-value of the composite (with a clear linear relationship), leaving a negative impact on the flexibility. Nonetheless, all the composites investigated exhibit elastic behaviours relative to the basic lime mortar. In particular, composite with cement addition up to $33 \%$ of the binder compositions exhibits deformation tendencies under compression. However, mortars with higher cement compositions (i.e. above 33\%) would strain linearly until failure occurs suddenly with minimal deformation. Substitution of lime with cement therefore has a significant impact on the microstructural compositions of lime mortar, and subsequent improvement on the performance of the composite. Despite the improved mechanical strengths, inherent flexibility of lime is maintained though negatively impacted, subject to the amount of lime substituted. Hence, relative to specific purposes, lime revival can be promoted in form of sustainable lime-cement composites.
\end{abstract}

masonry deformation. It has the flexibility to cushion masonry joints to absorb strains, prevent cracking and result in medium to high flexural bond strengths [2]. By virtue of its reasonably high flexibility, lime mortar exhibits low elastic modulus, thereby displaying capability to deform more on load application relative 
to Portland cement [3]. The modulus of rupture and the bond strength of an appropriate, well cured mature lime mortar are such that movement joints are not normally required in new (traditional) construction and any movement experienced (i.e. structural, seasonal and thermal) is taken up by minute adjustment over many joints due to their 'plastic' and 'self-healing' properties [4]-[6]. In addition, lime mortar possesses excellent permeability feature via its relatively large interconnected pore structures. These pore structures allow ice crystal growth in frost periods, thereby accommodating the crystals within the pore structures without causing deterioration of the matrix [7]-[9]. This feature enhances durability of lime mortars in a building fabric against environmental conditions. Lime mortar also exhibits phenomenal 'breathability' through which moisture and vapour transfer from the external environment are freely dissipated via its permeable material, in view of its capillary porosity. This enhances the performance of the materials and structure holistically $[2,7,10$, 11]. Lime mortars also have superior water retention as values from 94.2 to $99.5 \%$ have been consistently measured against those of $60-80 \%$ of Portland cement equivalents [2]. This property enhances workability which improves contact between mortar and substrate, thereby increasing bond.

With growing emphasis on the need for reduced energy consumption and minimised atmospheric $\mathrm{CO} 2$ concentration [12], continued use of lime mortar in building has significant environmental benefits: manufacture of limes consumes less energy and produces less greenhouse gases (compared with Portland cement); its exposure to the atmosphere as lime based mortars absorb most or all of the carbon dioxide that was driven off during its calcination, a phenomenon called re-carbonation; masonry laid using lime based mortar has lower bond strength (than cement) that the units can be prised off easily thereafter, thereby facilitating recycling of the materials, and; building structures finished with lime mortars are usually characterised with low thermal conductivity as this affects the interior surface temperatures of buildings, and may therefore perform better as an insulating material $[8,11,13]$.

Despite the properties as stated above, lime mortar is connected with exaggeratedly long setting and hardening periods, low internal cohesion, volumetric changes (i.e. shrinkage, particularly, aerial lime), relatively low mechanical strengths and a high water absorption capacity through capillarity. These have substantially impacted negatively on project delivery periods and significantly resulted in its relegation and relative disuse [9], [14]-[17]. To leverage some of the remarkable features particularly, flexibility, this situation therefore leads to the study of blended binding materials, in form of lime-cement composites.

Cement is a hydraulic material in nature because of its ability to set and harden under water by virtue of a chemical reaction with it $[18,19]$. It is characterised with high compressive strength and exhibits higher thermal expansion coefficient than most masonry. It hinders accommodation of movements resulting from creep or thermal effects, and exhibits negligible plastic deformation under load. Thus, it fails by brittle fracture [4], [20]-[26]. Effect of cement on porosity and pore size distribution of lime mortars is crucial since changes in microstructural features of lime can substantially modify its overall performances. In conservation works especially, cement is considered chemically incompatible with lime based mortars as it has low permeability, responsible for introduction of soluble salts and characterised with a high modulus of elasticity that is unfit for accommodation of masonry deformations [27]-[32]. It is also established that Portland cement reacts with carbonic acid to form alkali carbonate or bicarbonate salts which are undesirable. However if Portland cement is used in a small amount, this will remain a minor problem as previous works show that an increase in cement content does not proportionally increase the amount of soluble salts [30,33].

The evolving lime-cement composite would therefore share in the advantages of lime and cement mortars, avoiding or reducing their individual disadvantages [34]. These blended materials will be characterized by faster setting than lime and better flexibility than cement mortars, which generally improves their application [34]-[40]. The underlying purpose of this effort is driven by the need to improve lime mortar performances and reduce carbon dioxide emissions related to the production of cement [41]. It would also facilitate protection of the environment and conservation of energy resources along with the advent of a sizable market, for renewed interest in the use of lime as a building material $[14,42,43]$.

\section{Experimental Procedure}

\subsection{Materials and mortar Preparation}

Materials used for the present research have been products commercially available in the market. Natural Hydraulic Lime of the class NHL-5.0 (St Astiers, UK), characterised with the lime's highest compressive strength, based on the 28-day test [44] was adopted for this research. This lime type (NHL-5) was chosen based on its relatively short setting time for optimal strength yield, its availability, ease of handling, as well as the need to maximise lime performance behaviour [14, 45]. Table 1 shows Lime's average Particle Size Distribution obtained through laser diffraction method, using Laser Difractometry Xmastersize. This method is based on measurement of the laser beam scattered by the particle analysed. The distribution indicates particles with main equivalent diameter of $33.99 \mu \mathrm{m}$ (by volume) and $10.19 \mu \mathrm{m}$ (by Surface Area). $90 \%$ of these particles have sizes below $91.88 \mu \mathrm{m}$ (by volume). Lime's chemical compositions (by elements) determined by Energy Dispersive Spectrometry are given in Table 2. Cement (CEM I 52.5) for this investigation was obtained from 'Hanson Cement', United Kingdom. Its average Particle Size Distribution shown in Table 1 indicates particles with main equivalent diameter of $21.08 \mu \mathrm{m}$ (by volume) and $10.64 \mu \mathrm{m}$ (by Surface Area). $90 \%$ of these particles have sizes below $41.55 \mu \mathrm{m}$ (by volume). Cement's chemical compositions (by elements) are given in Table 2. Siliceous fine kiln dried sand, obtained from Fife Silica Sands (a division of Patersons of Greenoackhill Ltd, United Kingdom) constituted the aggregates. The aggregate was passed through a sieve analysis in accordance with the requirements of [46], and the particle size distributions in compliance with ASTM C 136 [47] are shown in Figure 1. The sand had Particle Size Distribution of $0-2 \mathrm{~mm}$ (i.e. $0.05 \mathrm{~mm}<\varnothing<2 \mathrm{~mm}$ ) which is considered suitable, in accordance with ASTM C 33 [48].

Following the required standard (BSI, 2000) [49], the mortars were prepared as the binder-aggregate $(\mathrm{B} / \mathrm{A})$ ratio was maintained at $1: 3$ by volume. This was chosen from the commonest dosage 
Table 1: Particle Size Diameters of the tested materials

\begin{tabular}{|l|l|l|l|l|l|l|l|}
\hline \multicolumn{2}{|c|}{ Parameters } & $\mathbf{d}(\mathbf{v}, \mathbf{0 . 5})$ & $\mathbf{d}(\mathbf{v}, \mathbf{0 . 1})$ & Mode & $\mathbf{d}(\mathbf{v}, \mathbf{0 . 9})$ & $\begin{array}{l}\mathbf{D}[\mathbf{4 , 3} \\
\text { (main } \\
\text { equivalent } \\
\text { diameter } \\
\text { by volume) }\end{array}$ & $\begin{array}{l}\text { D[3,2] } \\
\text { (main } \\
\text { equivalent } \\
\text { diameter } \\
\text { by Surface } \\
\text { Area) }\end{array}$ \\
\hline $\begin{array}{l}\text { Specified } \\
\text { Particle } \\
\text { Diameter } \\
(\boldsymbol{\mu m})\end{array}$ & Lime & 10.78 & 5.28 & 6.50 & 91.88 & 33.99 & 10.19 \\
\cline { 2 - 8 } & Cement & 20.14 & 5.40 & 31.78 & 41.55 & 21.08 & 10.64 \\
\hline
\end{tabular}

Table 2: Chemical Composition of the materials

\begin{tabular}{|l|l|l|l|l|l|l|l|l|l|l|l|l|l|}
\hline \multirow{3}{*}{ Material } & \multicolumn{8}{|c|}{ Elemental Chemical Composition of the materials (by \%eight of the dry specimen) } \\
\cline { 2 - 27 } & $\mathrm{Ca}$ & $\mathrm{O}$ & $\mathrm{Si}$ & $\mathrm{C}$ & $\mathrm{Sb}$ & $\mathrm{Al}$ & $\mathrm{Fe}$ & $\mathrm{Mg}$ & $\mathrm{S}$ & $\mathrm{K}$ & $\mathrm{Na}$ & $\mathrm{Ti}$ \\
\hline Lime & 47.6 & 37.6 & 5.2 & 4.4 & 3.3 & 0.7 & 0.5 & 0.5 & 0.2 & - & - & - \\
\hline Cement & 75.6 & 9.2 & 4.7 & - & 5.7 & 1.1 & 0.3 & 0.4 & 1.8 & 1.2 & 0.1 & - \\
\hline Sand & 0.2 & 53.5 & 43.0 & - & - & 1.6 & 0.4 & - & - & 1.1 & & 0.2 \\
\hline
\end{tabular}

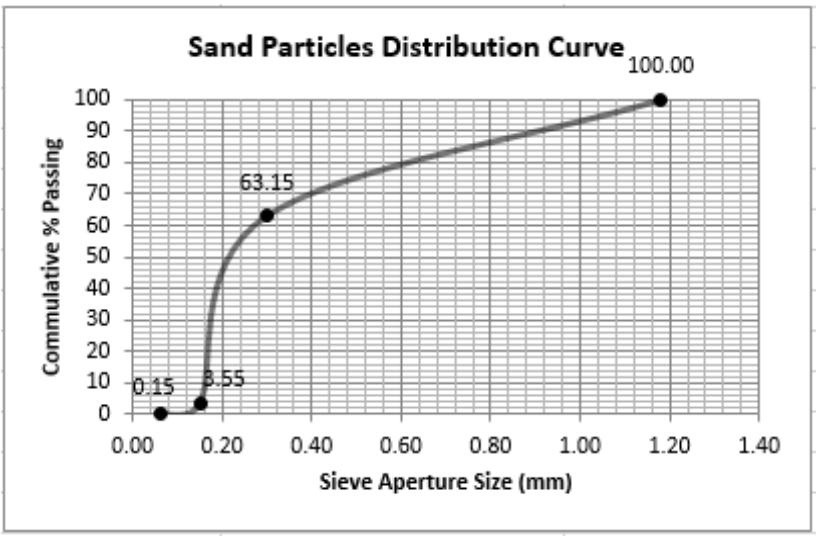

Figure 1: Grain size distribution of the aggregate

reported in the literature $[15,23,33,50]$. To avoid measurement imprecision during batching processes, volume proportions of components were converted to weights [2]. Mortar mixtures were prepared using the correct amount of water required to obtain adopted workability of $145 \pm 5 \mathrm{~mm}$ (measured by the flow table test - BS EN 1015-3 (BSI, 2000) [49] as BS EN 1015-6 (BSI, 1999) [51] specifies a flow value of ' $140-200 \mathrm{~mm}$ ' for 'plastic mortar'. Arising from visual and physical assessments of the mixes during the trial experimentation however, a flow value of $140-150 \mathrm{~mm}$ (i.e. $145+5 \mathrm{~mm}$ ) was adopted. As observed, either higher or lower value tends towards stiffness or fluidity respectively. This was determined in accordance with (BSI, 2005) [52].

Using the stated $\mathrm{B} / \mathrm{A}$ ratio (i.e. 1:3), each mortar formulation was prepared with progressively increasing/decreasing cement contents as indicated in Table 3. Mixing was done in the laboratory mixer of 30 litres maximum capacity. The mixing procedure was performed in a number of stages: Aggregates were placed first, followed by other dry materials (i.e. lime and cement, pre-mixed earlier, where applicable) and these were blended consistently for 60 seconds as best practice dictates that the NHL powder should be thoroughly mixed through the dry sand, ensuring batch colour consistency prior to gradually adding water. Water was added slowly during 30 seconds and mixing continued for another 30 seconds. Mixing was stopped for 90 seconds as mortar adhering to the wall and bottom of the mixer bowl was scraped off. Mixing then resumed to obtain consistent mixture. The entire mixing period lasted about 5 minutes. For every mortar mix, minimum of three prismatic specimens of $40 \times 40 \times 160 \mathrm{~mm}$ were prepared, the average value of which represented the 'actual value' for consideration during the specimen evaluations afterwards (i.e. for microstructural analysis, and mechanical characteristics evaluations: Flexural and Compressive tests; Moduli of Elasticity determination). The specimens were compacted with a vibration table after mould filling in prismatic casts (BSI, 2010b) [53], removed from the moulds 2 days later and left to cure at the laboratory ambient conditions of $21+4^{\circ} \mathrm{C}$ (temperature) and $40+5 \%$ (relative humidity), until the test dates of 1, 3, 6, 9 and 12 months.

\subsection{Analytical methodology}

This involved microstructural characteristics evaluation, mechanical properties assessment and some other relevant preliminary material testing. Microstructural characteristics of the mortar samples were evaluated in terms of the total porosity (in $\%$ ), median pore diameter (by volume in $\mathrm{nm}$ ), bulk density and pore size distribution, using Mercury Intrusion Porosimetry (MIP) technique. This was achieved with AutoPore IV 9500 by Micrometrics (with pressure range up to $60000 \mathrm{psi}$ ). The test was carried out with samples of approximately $1.5 \mathrm{~g}$ that were extracted from the core of the crushed prisms. Under short term loading and at a relatively low rate of load application (approximately $2 \mathrm{~mm} / \mathrm{min}$ ), the chance of micro crack propagation is minimum [33, 54]. These samples were obtained at the test ages of one and six months, and dried in an oven at temperature of $75 \pm 1{ }^{\circ} \mathrm{C}$ for 24 hours before the test, to ensure that the sample is devoid of moisture contents (which may otherwise affect its microstructural properties, thereby affecting the results). The mechanical properties were evaluated with regard to the three-point flexural tests, and compressive strength. While the flexural strength tests were performed on the ELE AutoTest 2000 apparatus with a load application pace of $50 \mathrm{~N} / \mathrm{s}$, compressive strength tests were conducted on the two fragments of each specimen (resulting from the preceding flexural test) using INSTRON 3367 with $30 \mathrm{kN}$ load capacity, moving at a loading rate of $2 \mathrm{~mm} / \mathrm{min}$. 
Table 3. Lime-Cement Mortars' Compositions by materials

\begin{tabular}{|c|c|c|c|c|c|c|}
\hline Cement Contents & $0 \%$ & $25 \%$ & $33 \%$ & $50 \%$ & $66 \%$ & $75 \%$ \\
\hline Mortar Reference I.D. & L13 & LC31 & LC21 & LC11 & LC12 & LC13 \\
\hline $\begin{array}{l}\text { Volumetric Ratio } \\
\text { (L-C-Sd) }\end{array}$ & $1-0-3$ & $3-1-12$ & $2-1-9$ & $1-1-6$ & $1-2-9$ & $1-3-12$ \\
\hline $\begin{array}{l}\text { Lime (L): Volume } \\
\text { (Volume in 'ml'/ } \\
\text { mass in ' } g \text { ') }\end{array}$ & $\begin{array}{c}1 \\
(1700 / \\
1172)\end{array}$ & $\begin{array}{c}3 \\
(770 / \\
528)\end{array}$ & $\begin{array}{c}2 \\
(665 / \\
458)\end{array}$ & $\begin{array}{c}1 \\
(850 / \\
586)\end{array}$ & $\begin{array}{c}1 \\
(510 / \\
352)\end{array}$ & $\begin{array}{c}1 \\
(260 / \\
176)\end{array}$ \\
\hline $\begin{array}{l}\text { Cement (C): Volume } \\
\text { (Volume in ' } \mathrm{ml} \text { '/ } \\
\text { mass in ' } \mathrm{g} \text { ') }\end{array}$ & $\begin{array}{c}0 \\
(0)\end{array}$ & $\begin{array}{c}1 \\
(415 / \\
442)\end{array}$ & $\begin{array}{c}1 \\
(540 / \\
574)\end{array}$ & $\begin{array}{c}1 \\
(830 / \\
883)\end{array}$ & $\begin{array}{c}2 \\
(995 / \\
1060)\end{array}$ & $\begin{array}{c}3 \\
(1250 / \\
1325)\end{array}$ \\
\hline $\begin{array}{l}\text { Sand (Sd): Volume } \\
\text { (Volume in 'ml'/ } \\
\text { mass in ' } \mathrm{g} \text { ') }\end{array}$ & $\begin{array}{c}3 \\
(4350 / \\
6444)\end{array}$ & $\begin{array}{c}12 \\
(4350 / \\
6444)\end{array}$ & $\begin{array}{c}9 \\
(4240 / \\
6283)\end{array}$ & $\begin{array}{c}6 \\
(4350 / \\
6444)\end{array}$ & $\begin{array}{c}9 \\
(3920 / \\
5800)\end{array}$ & $\begin{array}{c}12 \\
(4350 / \\
6444)\end{array}$ \\
\hline
\end{tabular}

The results reported in this work were all taken as an average value of six similar specimen fragments. Additionally, INSTRON 3367 plots stress/strain graph on the screen, with the value for Modulus of Elasticity generated automatically. Other Preliminary Material Testing carried out included: application of Scanning Electron Microscopy/Energy Dispersive X-ray Spectrometry using 'Carl Zeiss EVO 50' Scanning Electron Microscope to examine and analyse the microstructure, morphology and chemical composition characterizations of the experimental materials (Lime and cement); Laser Difractometry Xmastersize with air dispersion was adopted for determination of the Pore Size Distribution of the tested materials (Lime and cement), and; Consistency of fresh mortars was examined using the flow table test in accordance with (BSI, 2000) [49].

\section{Results and Discussion}

\subsection{Water/Binder Ratio}

Table 4 shows the results of the W/B ratios obtained for lime, and lime-cement mortars batched using varying binders' contents. Water/Binder (W/B) ratio was adjusted appropriately to ensure the same mortar flow of $145 \pm 5 \mathrm{~mm}$ for all the mixes. For the reference mortar (lime mortar, L13), W/B ratio was recorded at 1.53.

With progressive addition of cement content, a clear reduction of water demand was recorded, although non-linear. Thus, lime mortar exhibits its ability to retain water in the mix as it imparts plasticity and enhances workability $[2,4]$. Besides, this reduction in water demand could be attributed to quicker formation of more hydration products of Calcium Silicate Hydrates $(\mathrm{C}-\mathrm{S}-\mathrm{H})$ and resulting densification of the mortar matrix. It can therefore be inferred that increase in the percentage of lime with respect to cement mass requires a higher percentage of water in order to obtain a paste with the same consistency. This is because lime has smaller particle size with a higher specific surface. This leads to the mortar's finer pore system which results in higher suction and stronger water-retaining characteristics $[55,56]$.
Table 4: Lime-Cement Mortars' Compositions by materials and Water/Binder ratios.

\begin{tabular}{|c|c|c|c|}
\hline $\begin{array}{c}\text { Cement } \\
\text { Contents }\end{array}$ & $\begin{array}{c}\text { Mortar } \\
\text { Reference } \\
\text { I.D. }\end{array}$ & $\begin{array}{c}\text { Water } \\
\text { Content } \\
(\mathrm{g})\end{array}$ & $\begin{array}{c}\text { Water/ } \\
\text { Binder } \\
\text { Ratio }\end{array}$ \\
\hline $\mathbf{0 \%}$ & $\mathbf{L 1 3}$ & 1790 & 1.53 \\
\hline $\mathbf{2 5 \%}$ & $\mathbf{L C 3 1}$ & 1880 & 1.94 \\
\hline $\mathbf{3 3 \%}$ & $\mathbf{L C 2 1}$ & 1775 & 1.72 \\
\hline $\mathbf{5 0} \%$ & $\mathbf{L C 1 1}$ & 1800 & 1.23 \\
\hline $\mathbf{6 6 \%}$ & $\mathbf{L C 1 2}$ & 1680 & 1.19 \\
\hline $\mathbf{7 5 \%}$ & $\mathbf{L C 1 3}$ & 1710 & 1.14 \\
\hline
\end{tabular}

\subsection{Microstructural features}

Microstructural characteristics such as porosity and Pore Size Distribution (PSD) were evaluated for different mortars. Figures 2 (a) and (b), and Table 5 show the PSD curves and other microstructural data obtained by Mercury Intrusion Porosimetry (MIP) for the six different composites at 1 and 6 months of curing.

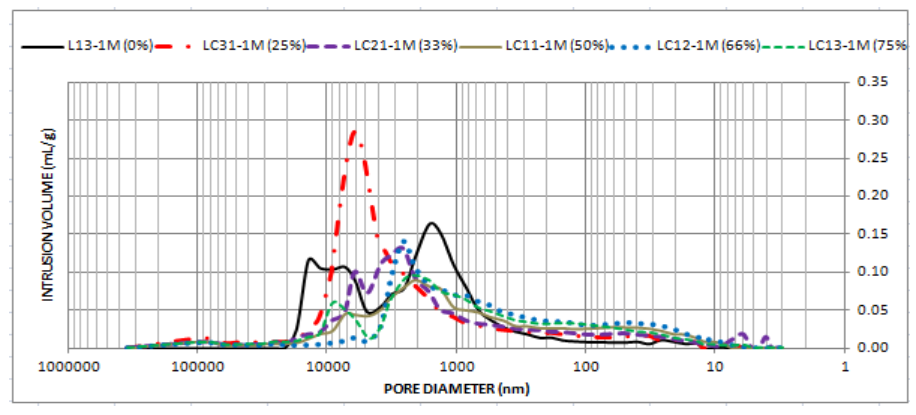

(a) 


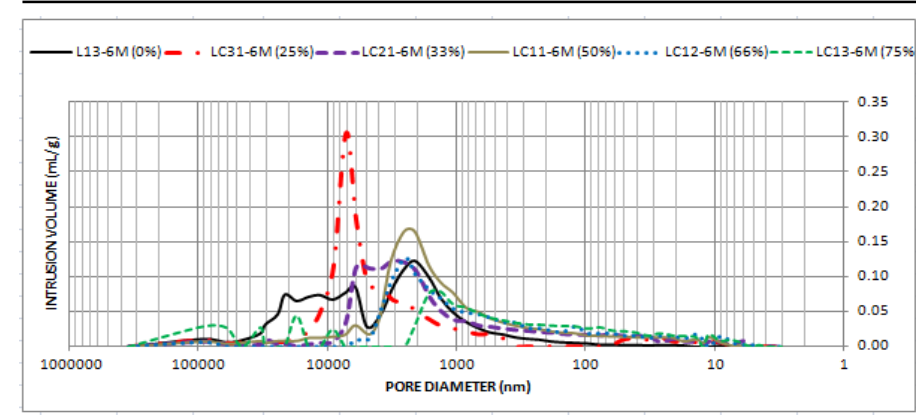

(b)

Figure 2: Pore size distribution for cured lime mortars with increasing cement contents: (a) At 1-month curing; (b) At 6-month curing

For lime only, at 1-month curing, the graph indicates a bimodal PSD with predominant sizes between $(0.5-5 \mu \mathrm{m})$ and $(5-20 \mu \mathrm{m})$ (Figure 2(a)). In this case, the mortar exhibits both gel pores (i.e. 1 $\mathrm{nm}-3 \mu \mathrm{m}$ ) and substantial proportion of capillary pores (i.e. 3-30 $\mu \mathrm{m})$. These large pores result from loss of excess unbound kneading water due to strong water-retaining characteristic of lime, and slow carbonation process [57]. The pores can also be related to fine cracks induced by associated drying shrinkage which can even expand and widen.

After 6 months, in spite of the continuous hydration and carbonation processes, the median pore diameter increased (from 2.16 to $3.96 \mu \mathrm{m}$ ) (Table 5) indicating more presence of larger pore sizes (i.e. between $0.5 \mu \mathrm{m}$ and $40 \mu \mathrm{m}$ ) with the shift of the PSD curves to the left (Figure 2 (b)). However, a reduction is observed in the total pore volume (i.e. from 27.77 to $23.42 \%$ ), which indicates filling of some of the capillary voids due to deposition of the hydration and carbonation products. The bulk density was also reduced (from 1.75 to $1.72 \mathrm{~g} / \mathrm{ml}$ ) due to evaporation of excess kneading water and subsequent drying shrinkage.
However, progressive addition of cement to the mortar resulted in unimodal PSD with lower median pore diameters and formation of finer pores at 6 months (Table 5). The graphs are shifted towards the right (relative to lime mortars), an indication of the dominance of smaller pore sizes.

The observed decrease in the median pore diameters is a consequence of lower W/B ratios used to achieve similar consistency. Also, it can be related to subsequent filling of larger pores by the hydration products particularly, C-S-H gel [58, 59, 60]. This can explain why the addition of cement led to predominance of smaller pore sizes in lime mortar. Usually, kneading water decreases with increasing cement content in the paste (as demonstrated in Section 3.2). This led to the densification of the mortar matrixes and consequent reduced porosities $(21.45 \%$ for LC31) at 6 months (Table 5).

\subsection{Mechanical Properties}

The results of the mortars' mechanical assessments (flexural strength, compressive strength and modulus of elasticity) for a 12 month curing period are summarised in Appendix I. Each result was taken as an average value of three similar specimens for flexural strength and five similar specimens for both compressive strength and modulus of elasticity. The coefficients of variation (COV) fall substantially within the lower range $(0-17 \%)$. This suggests consistent results. However, there were also few cases of higher $\mathrm{COV}$, which indicate some degree of scatter in those cases. Appropriate error bars are also displayed on the respective graphs.

For lime only, Figure 3 and (Appendix I) show a flexural strength value of $0.70 \mathrm{MPa}$ in the first month of curing which decreased to $0.61 \mathrm{MPa}$ at the end of 12 months. This may be due to formation of different pore sizes resulting from loss of excess unbound kneading water as revealed in the microstructural analyses above.

Table 5: Extracted Mercury Intrusion Porosimetry data for composite mortars containing increasing cement contents

\begin{tabular}{|c|c|c|c|c|}
\hline $\begin{array}{c}\text { Specimen } \\
\text { Reference } \\
\text { I.D. }\end{array}$ & $\begin{array}{c}\text { Curing } \\
\text { Period }\end{array}$ & $\begin{array}{c}\text { Median Pore } \\
\text { Diameter } \\
\text { (Volume) } \\
\text { [nm] }\end{array}$ & $\begin{array}{c}\text { Bulk Density } \\
\text { at 0.52psia } \\
\text { [g/mL] }\end{array}$ & $\begin{array}{c}\text { Porosity } \\
\text { [\%] }\end{array}$ \\
\hline \multirow{2}{*}{$\begin{array}{c}\text { L13 } \\
(0 \%)\end{array}$} & 1 Month & 2163.6 & 1.75 & 27.77 \\
\cline { 2 - 5 } & 6 Months & 3955.0 & 1.72 & 23.42 \\
\hline \multirow{2}{*}{$\begin{array}{c}\text { LC31 } \\
(25 \%)\end{array}$} & 1 Month & 4276.0 & 1.78 & 29.17 \\
\cline { 2 - 5 } & 6 Months & 6616.9 & 1.80 & 30.03 \\
\hline \multirow{2}{*}{$\begin{array}{c}\text { LC21 } \\
(33 \%)\end{array}$} & 1 Month & 3036.1 & 1.78 & 27.54 \\
\cline { 2 - 5 } & 6 Months & 2579.4 & 1.84 & 23.43 \\
\hline \multirow{2}{*}{$\begin{array}{c}\text { LC11 } \\
(50 \%)\end{array}$} & 1 Month & 1487.3 & 1.83 & 24.35 \\
\cline { 2 - 5 } & 6 Months & 1909.7 & 1.87 & 25.67 \\
\hline \multirow{2}{*}{$\begin{array}{c}\text { LC12 } \\
(66 \%)\end{array}$} & 1 Month & 989.4 & 1.86 & 25.51 \\
\cline { 2 - 5 } & 6 Months & 1340.8 & 1.92 & 20.81 \\
\hline \multirow{2}{*}{$\begin{array}{l}\text { LC13 } \\
(75 \%)\end{array}$} & 1 Month & 1372.1 & 1.86 & 24.64 \\
\cline { 2 - 5 } & 6 Months & 1033.7 & 1.90 & 21.45 \\
\hline
\end{tabular}


As anticipated, progressive addition of cement to the mortar increased the flexural strength throughout the curing period, though not in a linear trend. Cement with faster hydration, quicker formation of C-S-H, reduced pore sizes and volume, attained higher flexural strength at a relatively shorter time. Notably, LC12 recorded the highest values of $4.12 \mathrm{MPa}$ and $4.23 \mathrm{MPa}$ at 1 month and 12 months respectively.

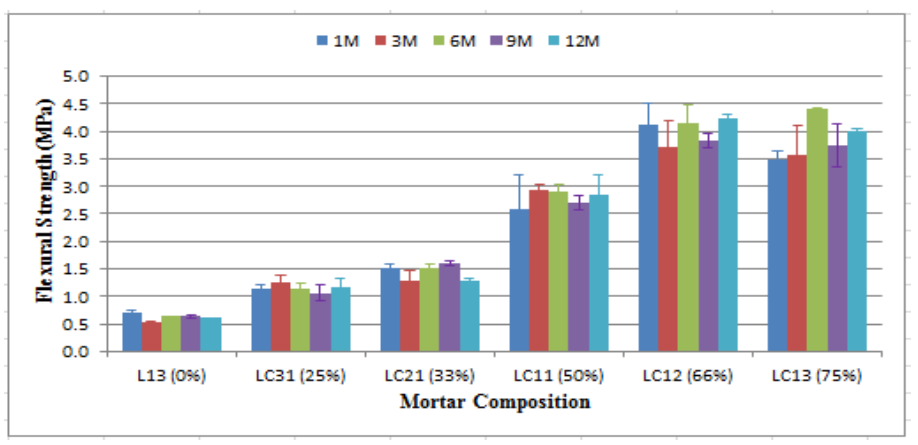

Figure 3: Flexural Strength developments for lime mortars with increasing cement contents

The compressive strength developments followed a similar trend to that of flexural strength. A marginal increase in the strength from $0.61 \mathrm{MPa}$ at 1 month curing to $0.66 \mathrm{MPa}$ at 12 months in the mix containing lime only was observed (Figure 4 and Appendix I).

Expectedly, these values significantly increased with progressive addition of cement. At 1 and 12 months of curing, highest values of 9.17 MPa and 12.34 MPa were recorded for the mix with triple cement content (LC13). This represents a significant increase (in each case) above the mix with no cement content (L13), over the same curing period.

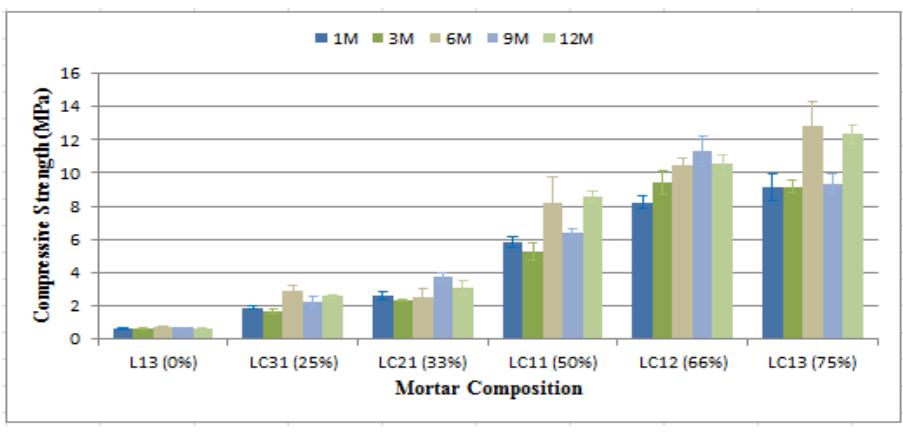

Figure 4: Compressive Strength developments for lime mortars with increasing cement contents

Despite increases recorded in both flexural and compressive strengths with increasing cement contents across the mixes, no significant increase was observed within each mix over the curing period. Being a hydraulic lime, the initial strength recorded may be related to the products of hydration reactions (i.e. formation of calcium silicate hydrates $(\mathrm{C}-\mathrm{S}-\mathrm{H})$ and calcium aluminate hydrates $(\mathrm{C}-\mathrm{A}-\mathrm{H})$ ). Subsequently the remaining bulk calcium hydroxide would be expected to react with atmospheric carbon dioxide through carbonation over time, for further strength developments. However, rate of carbonation is found to be strongly dependent on relative humidity [61]-[63]. The laboratory curing condition of $45 \%$ relative humidity is considered possibly low and could have impacted negatively on the carbonation process thereby leading to the insignificant strength gains over time. Nonetheless, observed impact of the low humidity on the results may be applicable and relevant in some geographical regions, where the humidity is not always very high (e.g. tropical regions like Nigeria, among others).

The compressive strength recorded in each case is related to the mortars' practical performance. This is as reflected in their moduli of elasticity (E) values as shown in Appendix I and Figures 5 to 7.

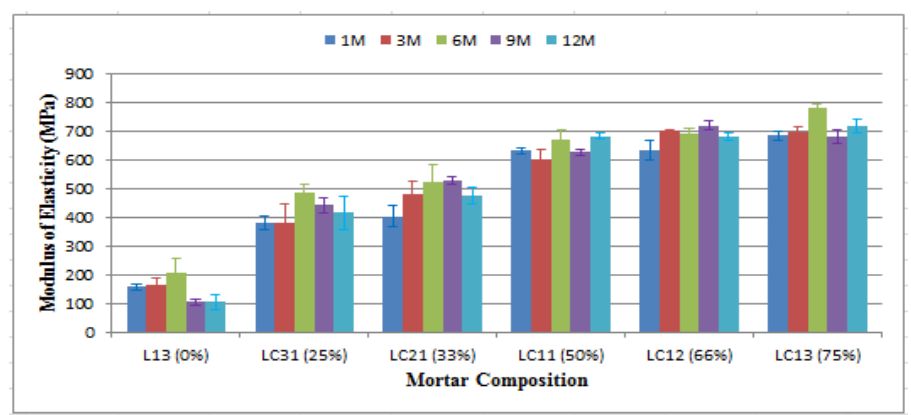

Figure 5: Moduli of elasticity (E) values for lime mortars with increasing cement contents

From Figure 5, L13 with the least compressive strength correspondingly recorded lowest ' $\mathrm{E}$ ' value over the 12-month curing period. Also, LC13 with the highest compressive strength correspondingly recorded the highest ' $\mathrm{E}$ ' value over the same curing period. Both LI3 and LC13 have the tendencies to display contrasting elastic behaviours (high and low) respectively. This is supported with the mortars' Compressive/Flexural strength ratios $\left(f_{c} / f_{f}\right)$ and Moduli of Elasticity relationships with increasing cement contents as illustrated in Figure 6. It is well established that low compressive to flexural strength ratio $\left(f_{c} / f_{f}\right)$ of similar materials is proportional to the Modulus of Elasticity (E-value) which is inversely proportional to its elastic behavior [64, 65]. Figure 6 presents the relationships between $\left(f_{c} / f_{f}\right)$ and the E-values with cement contents for studied lime mortars. The dotted arrow on the graph indicates the general tendency of the E-values with respect to the increase in cement contents.

From Figure 6, it can be observed that both $\left(f_{c} / f_{f}\right)$ and the Evalues are proportional to cement content. However, these relationships are not linear over the 12-month curing period. Figures 7 (a) and (b) show further analyses to determine any potential pattern of relationships between the parameters

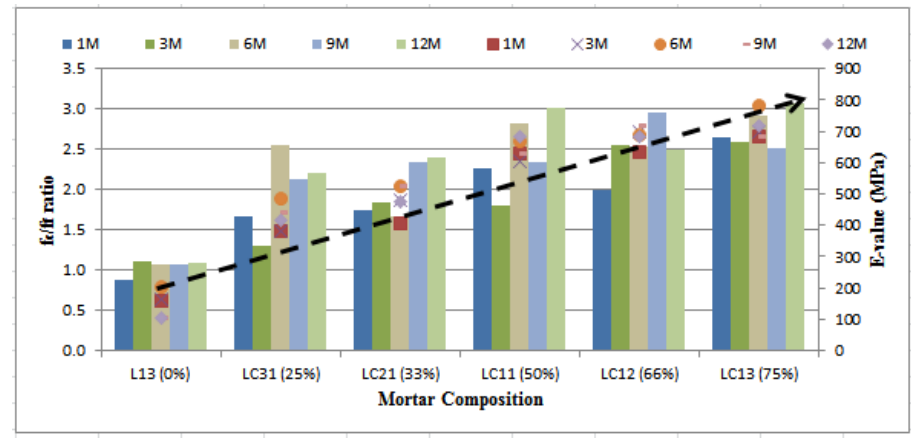

Figure 6: Compressive/Flexural strength ratios (fc/ff) and Moduli of Elasticity versus lime and cement mortars over 12-month curing (general relationships)

As can be observed from Figures 7 (a) and (b), good relationships could be established between $\left(f_{c} / f_{f}\right)$ and cement 
contents (with correlation coefficients above 0.80 obtained in each case). The relationship is described by the quadratic equation $\left(\mathrm{R}^{2}=0.89\right)$ :

$$
f_{c} / f_{f}=-4.14 c^{2}+5.46 c+1.09
$$

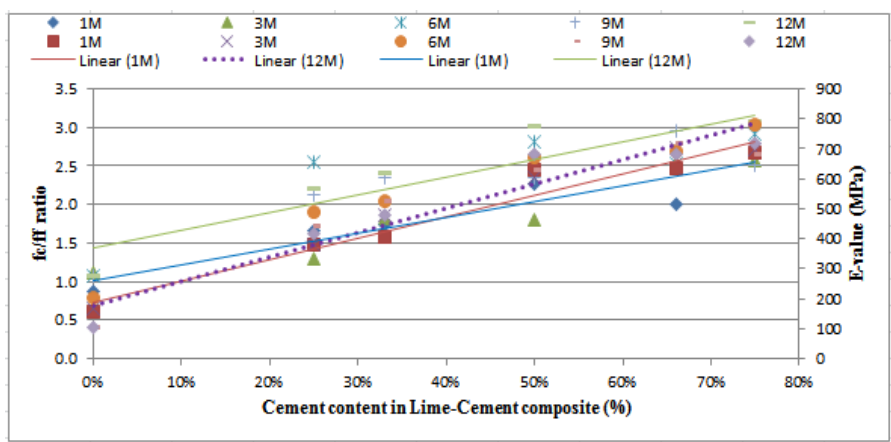

$f_{c} / f_{f}:$ Linear equation for the relationship at:

1 -month $\left(f_{d} / f_{f}=2.04 c+1.02\right) ; R^{2}=0.8715$

12 months $\left(f_{c} / f_{f}=2.28 c+1.44\right) ; R^{2}=0.765$

E-value: Linear equation for the relationship at:

1-month $(T c=712.91 E+187)$;

12 months $(T c=807.79 E+178.65) ; R^{2}=0.9166$

(Note: Tc: Thermal Conductivity; $c$ is cement content in \%; E is E-value) (a)

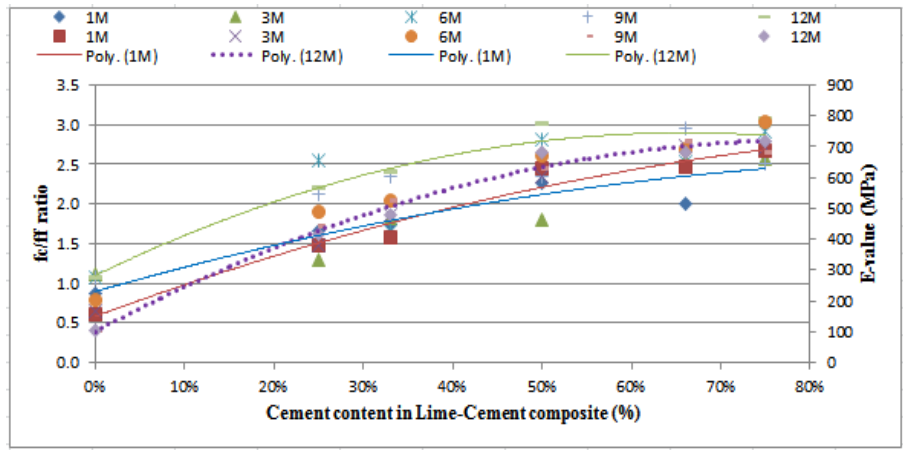

$f_{c} / f_{f}:$ Quadratic equation for the relationship at:

1 -month $\left(f_{c} f_{f}=-1.52 c^{2}+3.21 c+0.89\right) ; R^{2}=0.8972 ; 12$ months $\left(f_{d} f_{f}=-4.14 c^{2}+\right.$ $5.46 c+1.09) ; R^{2}=0.8985$

E-value: Quadratic equation for the relationship at:

1-month $\left(E=-462.6 c^{2}+1068.5 c+148.86\right) ; R^{2}=0.9674 ; 12$ months $(E=$ $\left.964.31 c^{2}+1549.1 c+99.155\right) ; R^{2}=0.9856$

(Note: Tc: Thermal Conductivity; $c$ is cement content in \%; E is E-value)

(b)

Figure 7: Compressive/Flexural strength ratios $\left(f_{d} f_{f}\right)$ and Moduli of Elasticity versus cement content for lime and cement mortars: (a) Through linear relationships; (b) Relationships using polynomial curves

However, a strong relationship could be established between the E-value and cement content. This relationship is described by the quadratic equation with a high correlation coefficient $\left(\mathrm{R}^{2}=\right.$ 0.99):

$$
E=-964.31 c^{2}+1549.1 c+99.155
$$

where $\mathrm{E}$ is $\mathrm{E}$-value, and $\mathrm{c}$ is cement content in \%.

\section{Further Results Synthesis: Changing Microstructural Compositions vis-à-vis Lime Composites' Flexibility}

The changing microstructural characteristic features of the lime-based mortars are related to the mortar's modulus of elasticity (E-value).

Figure 8 (a) presents the effect of cement content, on both porosity and E-value. While porosity is inversely proportional to www.astesj.com cement content, E-value is directly proportional. The dotted arrows on the graph indicate the increasing pattern of the E-values for 1 and 6 months curing.

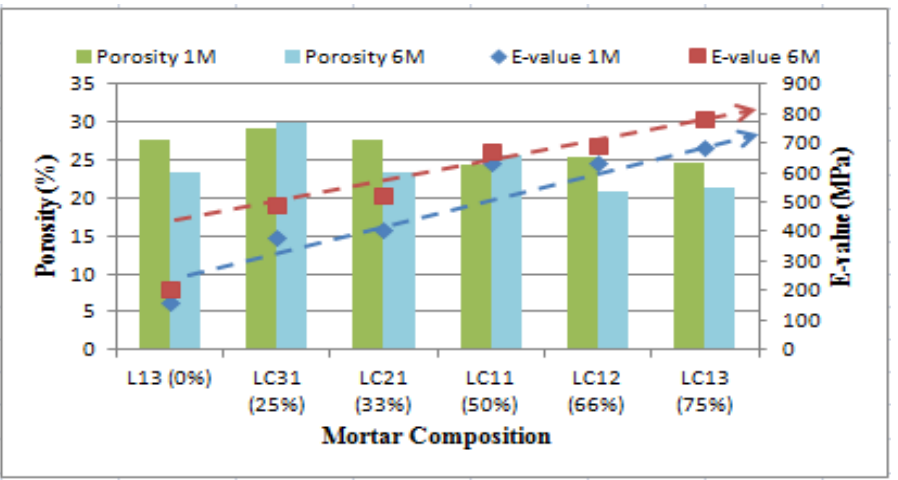

(a)

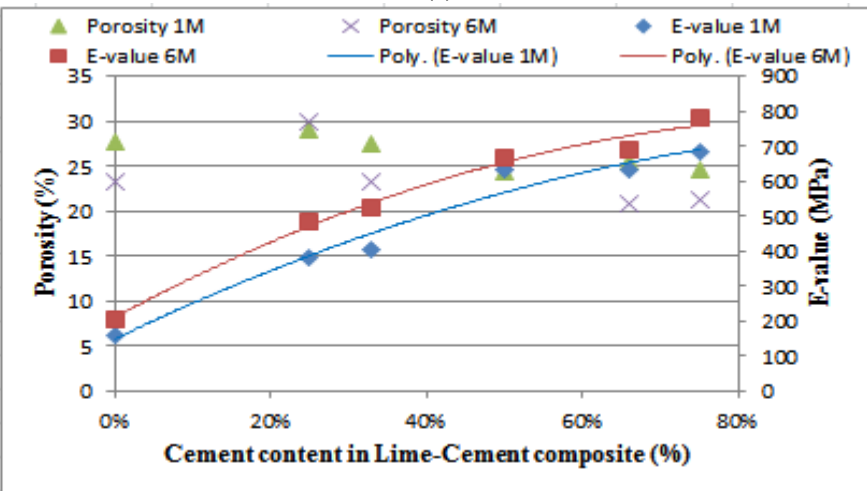

E-value: Quadratic equation for the relationship at:

1-month $\left(\mathrm{E}=-462.6 c^{2}+1068.5 c+148.861\right) ; R^{2}=0.9674$;

6-months $\left(E=-626.12 c^{2}+1199.6 c+210.65\right) ; R^{2}=0.9868$;

(Note:p is porosity; c is cement content in \%)

(b)

Figure 8: Relationships between increase in cement content, porosity and Evalue of Lime mortar at 1 and 6-month curing: (a): General relationships;

(b): Relationships using polynomial curves

An attempt was made to approximate these experimental results by establishing mathematical relationships between cement content and porosity as well as E-values, using quadratic equations (Figure 8 (b)). Considering composite performance at 6 months, a clear relationship can be established between cement content (c) and E-value (E) as expressed in the following equation:

$$
E=-626.12 c^{2}+1199.6 c+210.65
$$

The coefficient of correlation in this case is very high (0.99), indicating a very strong relationship

Lime mortar is primarily popular for its flexibility, the basis of its ability to accommodate masonry deformation. With the presence of lime (in varying compositions), both LI3 and LC13 (with the least lime content) have the tendencies to display contrasting elastic behaviours (high and low) respectively, as demonstrated in their stress-strain relationships at 1, 6, 9 and 12 months of curing respectively (Figures 9 (a) to (d)), with varying capacities to absorp deformation. The trend is also applicable to other mixes. 


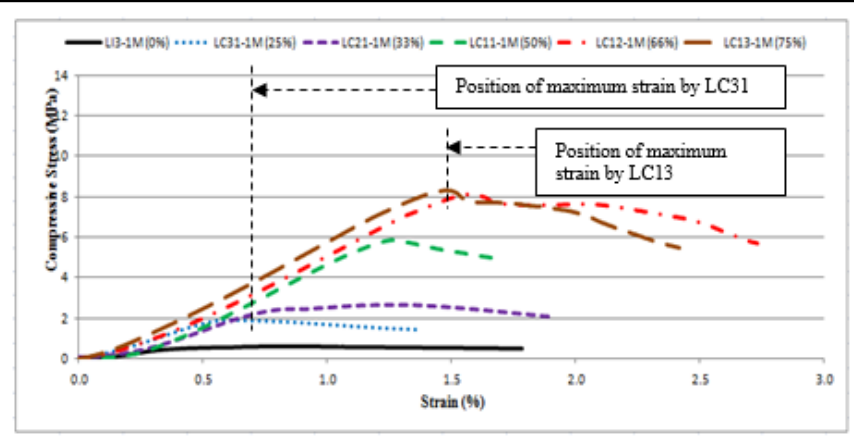

(a)

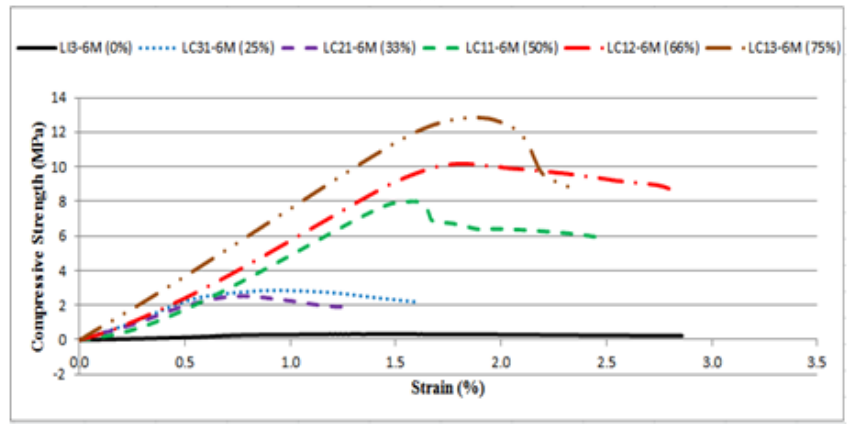

(b)

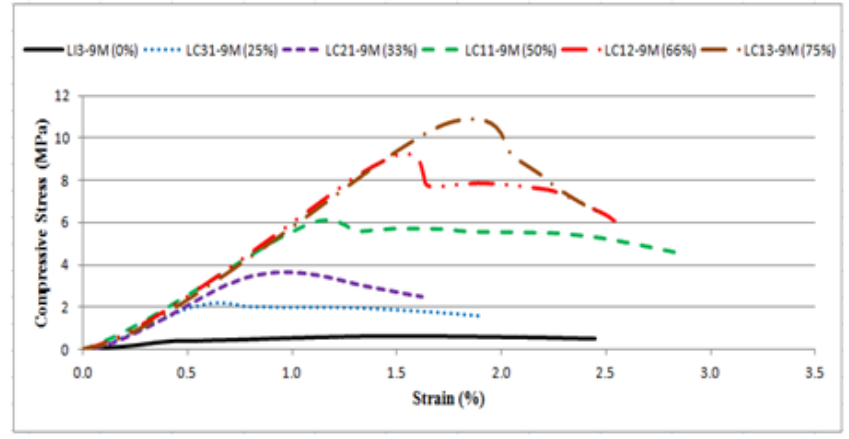

(c)

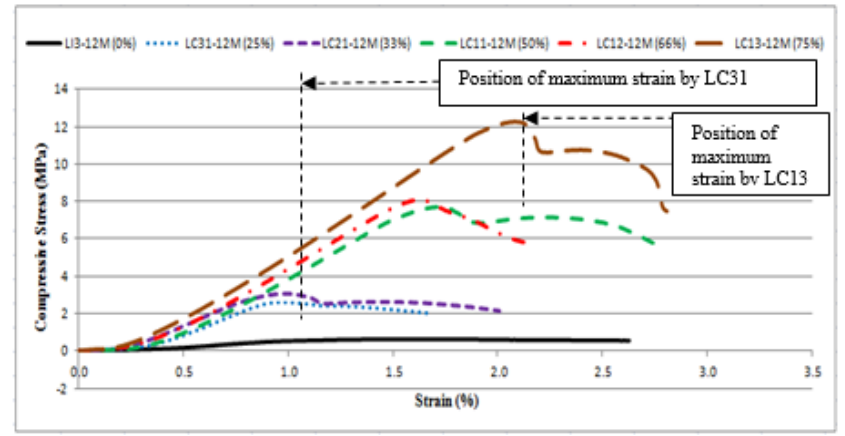

(d)

Figure 9: Compressive Strength versus Strain relationships for lime and limecement mortars at different curing ages: (a): At 1-month curing; (b): At 6-month curing; (c): At 9-month curing; (d): At 12-month curing

The smaller the slope of the curve, the better the elastic behaviour. All mortars exhibit comparably varying slopes relative to lime mortar's (L13). Compressive stress varies proportionally with increasing cement content as shown on the individual behavioural patterns for lime-cement composites (Figures 9 (a) to (d)). For example, the specimen with the highest cement content (75\% cement content i.e. LC13) sustained about $8 \mathrm{MPa}$ and 12 $\mathrm{MPa}$ maximum compressive stresses after 1 and 12 months respectively. This differs significantly from the maximum compressive stresses of $2 \mathrm{MPa}$ and $3 \mathrm{MPa}$ sustained by the www.astesj.com composite with the least cement content $(25 \%$ cement content i.e. LC31). However, increasing cement content is associated with higher slope of the curve, having attendant negative consequences on the strain, and the ability of the sample to sustain deformation. This results in decreasing flexibility.

Thus, LC13 curve with the highest gradient is characterised with the least flexibility, and thus, the least capability to sustain deformation before failure. Nevertheless, cement content at about $33 \%$ of the binders produces composite with comparable flexibility relative to lime mortar. This is evident in LC31 and LC21. In general, cement addition up to $33 \%$ of the binder compositions would enable the mortars under compression to exhibit some deformation tendencies. The smaller the slope of the curve, the better the elastic behaviour. All mortars exhibit comparably varying slopes relative to lime mortar's (L13). Compressive stress varies proportionally with increasing cement content as shown on the individual behavioural patterns for limecement composites (Figures 9 (a) to (d)). For example, the specimen with the highest cement content $(75 \%$ cement content i.e. LC13) sustained about $8 \mathrm{MPa}$ and $12 \mathrm{MPa}$ maximum compressive stresses after 1 and 12 months respectively. This differs significantly from the maximum compressive stresses of 2 $\mathrm{MPa}$ and $3 \mathrm{MPa}$ sustained by the composite with the least cement content $(25 \%$ cement content i.e. LC31). However, increasing cement content is associated with higher slope of the curve, having attendant negative consequences on the strain, and the ability of the sample to sustain deformation. This results in decreasing flexibility. Thus LC13 curve with the highest gradient is characterised with the least flexibility, and thus, the least capability to sustain deformation before failure. Nevertheless, cement content at about $33 \%$ of the binders produces composite with comparable flexibility relative to lime mortar. This is evident in LC31 and LC21. In general, cement addition up to 33\% of the binder compositions would enable the mortars under compression to exhibit some deformation tendencies. However, mortars with higher cement compositions (i.e. above 33\%) would strain linearly until failure occurs, and failure appears suddenly with minimal deformation.

\section{Conclusion}

This study has presented empirical data to reveal synergies obtainable by taking the advantage of respective useful features of each of lime and cement, combined as mortar constituents. The study sought to evolve low carbon composite construction materials in forms of 'lime-cement' mortars with cement serving as a partial replacement for lime in each case. Through this process, potential benefits derivable from blending lime and cement are revealed, particularly, maximizing 'flexibility' feature of lime mortar. This is a primary lime property essentially responsible for its age-long durability. However, due to other prominent drawbacks associated with lime, its overall usage has gone to decline. Thus, it is clear from this study that the patterns exhibited by all the composites investigated suggest that they are relatively characterized by elastic behaviours comparable to the basic lime-based mortar. In particular, cement addition up to $33 \%$ 
of the binder compositions would enable the mortars under compression exhibit some deformation tendencies. However, mortars with higher cement compositions (i.e. above 33\%) would strain linearly until failure occurs suddenly, with minimal deformation. This study therefore is an attempt to revive sustainable lime mortar as a direct response to the climate change challenge in view of the material's sustainability characteristics. Conclusively, this effort would facilitate protection of the environment and conservation of energy resources along with the advent of a sizable market, for renewed interest in the use of lime as a building material.

\section{Conflict of Interest}

The author declares no conflict of interest.

\section{Acknowledgment}

The authors gratefully acknowledge the financial supports from 'TETFUND AST\&D' Scheme, an educational development organ of The Federal Government of Nigeria. Thanks, are also due to Hanson Cement, United Kingdom, for the provision of the cement used for this work.

\section{References}

[1] D. Zhang, J. Zhao, D. Wang, C. Xu, M. Zhai, X. Ma, "Comparative study on the properties of three hydraulic lime mortar systems: Natural hydraulic lime mortar, cement-aerial lime-based mortar and slag-aerial lime-based mortar" Constr. Build. Mater, 186, 42-52, 2018 https://doi.org/10.1016/j.conbuildmat.2018.07.053

[2] R. Hanley, S. Pavía, "A study of the workability of natural hydraulic lime mortars and its influence on strength", Mater. Struct, 41(2), 373-381, 2008.

[3] S. Pavia, O. Brennan, "Portland cement-lime mortars for conservation", 3rd Historic Mortars Conference (HMC13) held at the University of the West of Scotland Glasgow, Scotland, 2018.

[4] E.A.W. Hendry, "Masonry walls: material and construction", Constr. Build. Mater, 15, 323-33, 2001. https://doi.org/10.1016/S0950-0618(01)00019-8

[5] R. J. Ball, A. El-Turki, W.J. Allen, J.A. Nicholson, G.C. Allen, "Deformation of NHL3.5 and CL90/PC hybrid mortars", Proceedings of the Institution of Civil Engineers - Constr. Mater., 162(1), 29-35, 2009. Doi: 10.1680/coma.2009.162.1.29

[6] P. Faria, F. Henriques, V. Rato, "Comparative evaluation of lime mortars for architectural conservation", J Cult Herit, 9(3), 338-346, 2008.

[7] A.M. Forster, "An assessment of the relationship between the water vapour permeability and hydraulicity of lime based mortars with particular reference to building conservation materials science", PhD Thesis, Heriot-Watt University, Edinburgh, 2002.

[8] G. Cultrone, E. Sebastián, M.O. Huertas, "Forced and natural carbonation of lime-based mortars with and without additives: Mineralogical and textural changes". Cement and Concrete Res., 35(12), 2278-2289, 2005.

[9] A. Isebaert, W. De Boever, V. Cnudde, L. Van Parys, "An empirical method for the estimation of permeability in natural hydraulic lime mortars" Mater. Struct., 49(11), 4853-4865, 2016. https://doi.org/10.1016/S09500618(01)00019-8

[10] A.J. Klemm, D.E. Wiggins "Lime mortar and sacrificial protection of heritage stonework" Proceedings of the Institution of Civil Engineers Engineering History and Heritage, 168(4), 167-176, 2015.

[11] A.J. Edwards "Properties of Hydraulic and Non-hydraulic Limes for Use in Construction" PhD Thesis, Napier University, Edinburgh, 2005.

[12] K. AL-Bashaireh "Lime Mortar and Plaster from The House XVII-XVIII, Umm El-Jimal, Jordan: Archaeometric Analysis. Shedet, Annual PeerReviewed Journal issued by The Faculty of Archaeology, Fayoum University, 6, 212-224, 2019. https://doi.org/10.36816/shedet.006.12

[13] S.A. Olaniyan, A.J. Klemm, F.C. Almeida, "Evolving Low Carbon Sustainable Building Material: Making Case for Cement-Lime Composites" 9th International Concrete Conference on Environment, Efficiency and Economic Challenges for Concrete, Dundee, 2016.
[14] S.A. Olaniyan, "Sustainable Lime Based Mortars: Performance Assessment of Composites for Building Construction" PhD Thesis, Glasgow Caledonian University, Glasgow, Scotland (UK), 2017.

[15] L. Ventola, M. Vendrell, P. Giraldez, "Newly-designed traditional lime mortar with a phase change material as an additive" Constr. Build. Mater, 47, 1210-1216, 2013

[16] F. Pacheco-Torgal, J. Faria, S. Jalali, "Some considerations about the use of lime-cement mortars for building conservation purposes in portugal: A reprehensible option or a lesser evil?" Constr. Build. Mater, 30(1), 488-494, 2012.

[17] A. Izaguirre, J. Lanas, J.I Alvarez, "Effect of a polypropylene fibre on the behaviour of aerial lime-based mortars" Constr. Build. Mater, 25(2), $992-$ 1000, 2011. https://doi.org/10.36816/shedet.006.12

[18] A. Everett, Materials (4th ed.). London, Harlow: Longman, 1986.

[19] A.M. Neville, Properties of Concrete (4th ed.). Harlow: Longman Scientific \& Technical, 1995

[20] L. Mcdonald, "Hydraulic lime mortar for the house of the future" Structure Engineer, 78 (7), 2000

[21] K. Callebaut, J. Elsen, K. Van Balen, W. Viaene, "Nineteenth century hydraulic restoration mortars in the saint Michael's church (leuven, belgium)" Cement Concrete Res., 31(3), 397-403, 2001.

[22] K. Elert, C. Rodriguez-Navarro, E.S. Pardo, E. Hansen, O. Cazalla, "Lime mortars for the conservation of historic buildings" Stud. Conserv., 47, 62-75, 2002.

[23] A. Moropoulou, A.S. Cakmak, G. Biscontin, A. Bakolas, E. Zendri, "Advanced byzantine cement based composites resisting earthquake stresses: The crushed brick/lime mortars of justinian's hagia Sophia" Constr. Build. Mater, 16(8), 543-552, 2002.

[24] M. P. Seabra, H. Paiva, J.A. Labrincha, V.M. Ferreira, "Admixtures effect on fresh state properties of aerial lime based mortars" Constr. Build. Mater, 23(2), 1147-1153, 2009. doi: 10.36816/006.12

[25] A.M. Forster, K. Carter, "A framework for specifying natural hydraulic lime mortars for masonry construction" Structural Survey, 29(5), 373-396, 2011.

[26] C. Ince, Y. Ozturk, M. Carter, M. Wilson, "The influence of supplementary cementing materials on water retaining characteristics of hydrated lime and cement mortars in masonry construction" Mater Struct., 47(3), 493-501, 2013. Doi: $10.1617 / \mathrm{s} 11527-013-0074-9$

[27] M. Tate, "The most important property of cement-lime mortar in masonry construction" International Building Lime Symposium Orlando, Florida, March $9-11,2005$

[28] J. Hughes, J.E. Lindqvist, CBI Betonginstitutet AB, SP - Sveriges Tekniska Forskningsinstitut, and RISE "RILEM TC 203-RHM: Repair mortars for historic masonry: The role of mortar in masonry: An introduction to requirements for the design of repair mortars" Mater Struct, 45(9), 1287 1294,2012

[29] S.A. Olaniyan, A.J. Klemm, "Current Trends in Development of Lime Based Composites" Building Physics in Theory and Practice, 7(3), 49-54, 2015.

[30] F. Pacheco-Torgal, J. Faria, S. Jalali, "Some considerations about the use of lime-cement mortars for building conservation purposes in portugal: A reprehensible option or a lesser evil?" Construction and Building Materials, 30(1), 488-494, 2012.

[31] C. Torney, A.M. Forster, E.M. Szadurski, "Specialist 'restoration mortars' for stone elements: A comparison of the physical properties of two stone repair materials" Heritage Science, 2(1), 1-12, 2014.

[32] C. Torney, A.M. Forster, "Concerned with compatibility" Building Surveying Journal, 28, 2015.

[33] M.J. Mosquera, B. Silva, B. Prieto, E. Ruiz-Herrera, "Addition of cement to lime-based mortars: effect on pore structure and vapor transport" Cement Concrete Res. 36, 1635- 1642, 2006

[34] M. Arandigoyen, J.I. Alvarez, "Blended pastes of cement and lime: pore structure and capillary porosity" Applied Surface Science, 252(23), 8077 $8085,2006$.

[35] P.F.G. Banfill, "The rheology of fresh mortar" Magazine of Concrete Research, 154(43), 13-21, 1991.

[36] P.F.G. Banfill, "Rheological methods for assessing the flow properties of mortar and related materials" Constr. Build. Mater, 8(1), 43-50, 1994.

[37] M. Arandigoyen, J. I. Alvarez, "Pore structure and mechanical properties of cement-lime mortars" Cement and Concrete Res., 37(5), 767-775, 2007.

[38] V. Starinieri, D.C. Hughes, D. Wilk, "Influence of the combination of Roman cement and lime as the binder phase in render mortars for restoration" Constr. Build. Mater, 44, 192-199, 2013.

[39] T.H. Park, C.K. Park, M.H. Noh, "Rheological properties of cementitious materials containing mineral admixtures" Cement and Concrete Res., 35(5), 842-849, 2005. https://doi.org/10.1016/j.cemconres.2004.11.002 
[40] R. Artis "Admixtures and Additives for Lime Mortars" An online publication of 'The Building Conservation Directory', 2014. http://www.buildingconservation.com/articles/lime-mortar-additives/limemortar-additives.htm, retrieved in September, 2016.

[41] J. Stark, "Recent advances in the field of cement hydration and microstructure analysis" Cement and Concrete Res., 41(7), 666-678, 2011.

[42] Y. Sébaïbi, R.M. Dheilly, B. Beaudoin, B., M. Quéneudec, "The effect of various slaked limes on the microstructure of a lime-cement-sand mortar" Cement and Concrete Res., 36(5), 971-978, 2006. https://doi.org/10.1016/j.cemconres.2011.03.028

[43] M. Arandigoyen, J.I. Alvarez, "Pore structure and mechanical properties of cement-lime mortars" Cement and Concrete Res., 37(5), 767-775, 2007.

[44] British Standards Institution (BSI) BS EN 998: Masonry Mortar - Part 2: Specification for Mortar for Masonry, 2010a.

[45] A. Moropoulou, "Reverse engineering: a proper methodology for compatible restoration mortars" RILEM Conference Proceedings on Historic Mortars, Delft, 2005.

[46] British Standards Institution (BSI) BS EN 13139: Aggregates for mortar Part 3 (PD 6682): Guidance on the use of BS EN 13139, 2013.

[47] ASTM C136 "Standard Test Method for particle size distributions", 2014

[48] ASTM C 33 "Standard Specification for mortar Aggregates", 2016

[49] British Standards Institution (BSI) BS EN 1015: Methods of Test for Mortar for Masonry - Part 3: Determination of Consistence of Fresh Mortar (by Flow Table), 2000.

[50] J. Lanas, J.I. Alvarez-Galindo, "Masonry repair lime-based mortars: Factors affecting the mechanical behaviour" Cement and Concrete Res., 33(11), 1867-1876, 2003. https://doi.org/10.1016/S0008-8846(03)00210-2

[51] British Standards Institution (BSI) BS EN 1015: Methods of Test for Mortar for Masonry - Part 6: Determination of Bulk Density of Fresh Mortar, 1999.

[52] British Standards Institution (BSI) PD 6678: Published Document - Guide to the Specification of the Masonry Mortar, 2005.

[53] British Standards Institution (BSI) BS EN 459: Building Lime - Part 2: Test Method, 2010b.

[54] J.S. Pozo-Antonio, "Evolution of mechanical properties and drying shrinkage in lime-based and lime cement-based mortars with pure limestone aggregate" Constr. Build. Mater, 77, 472-478, 2015.
[55] K.M. Green, M.A. Carter, M. A.D. Hoff, M.A. Wilson, "The effects of lime and admixtures on the water-retaining properties of cement mortars" Cement Concrete Res., 29(11), 1743-1747, 1999.

[56] Y. Sébaïbi, R.M. Dheilly, M. Quéneudec, "A study of the viscosity of limecement paste: Influence of the physico-chemical characteristics of lime" Constr. Build. Mater, 18(9), 653-660, 2004.

[57] K. Aligizaki, Pore Structure of Cement-Based Materials: Testing, Interpretation and Requirements. Taylor and Francis, 2006.

[58] J. Grilo, P. Faria, R. Veiga, A.S.Silva, V. Silva, A. Velosa, "New natural hydraulic lime mortars - physical and microstructural properties in different curing conditions" Constr. Build. Mater, 54, 378-384, 2014. https://doi.org/10.1016/S0008-8846(03)00210-2

[59] G. Land, D. Stephan, D. "Controlling cement hydration with nanoparticles" Cement and Concrete Comp., 57, 64-67, 2015.

[60] Y.C. Choi, Y. K. Cho, K. Shin, K., S. Kwon, "Development and application of microcapsule for cement hydration control" KSCE Journal of Civil Engineering, 20(1), 282-292, 2015.

[61] A. El-Turki, M.A. Carter, M.A. Wilson, R.J. Ball, G.C. Allen, "A microbalance study of the effects of hydraulicity and sand grain size on carbonation of lime and cement" Constr. Build. Mater, 23(3), 1423-1428, 2009. https://doi.org/10.1016/j.cemconres.2009.03.028

[62] A. El-Turki, R.J. Ball, S. Holmes, G.C. Allen, W.J. Allen, "Environmental cycling and laboratory testing to evaluate the significance of moisture control for lime mortars" Constr. Build. Mater, 24(8), 1392-1397, 2010. https://doi.org/10.1016/ 11.002

[63] V. Pavlik, M. Uzakova, M. "Effect of curing conditions on the properties of lime, lime-metakaolin and lime-zeolite mortars" Constr. Build. Mater, 103, $14-25,2016$

[64] A. Moropoulou, A. Bakolas, P. Moundoulas, E. Aggelakopoulou, S. Anagnostopoulou, "Strength development and lime reaction in mortars for repairing historic masonries" Cement and Concrete Comp., 27(2), pp 289294, 2005.

[65] B.S. Briccoli, L. Rovero, "Gli additivi per malte usati nell' antichita, Ed. Mascolo G, Materiali e tecniche per il Restauro Cassino" Idea Stampa Editore AIMAT, INISM, 1997 
Appendix I. Lime and Lime-Cement Mortars' Mechanical Strength Results over 12 month curing periods

\begin{tabular}{|c|c|c|c|c|c|c|c|}
\hline \multirow{2}{*}{$\begin{array}{c}\text { Mortar } \\
\text { Reference } \\
\text { I.D. }\end{array}$} & \multirow{2}{*}{$\begin{array}{c}\text { Volumetric } \\
\text { Ratio } \\
(\mathrm{L}-\mathrm{C}-\mathrm{Sd})\end{array}$} & \multirow{2}{*}{$\begin{array}{c}\text { Mechanical } \\
\text { Parameters } \\
(\mathrm{MPa})\end{array}$} & \multicolumn{5}{|c|}{ Curing Period (month(s)) } \\
\hline & & & 1 & 3 & 6 & 9 & 12 \\
\hline \multirow{3}{*}{$\begin{array}{l}\text { L13 } \\
(0 \%)\end{array}$} & \multirow{3}{*}{$1-0-3$} & $\begin{array}{c}\text { Flexural } \\
(\mathrm{COV}(\%))\end{array}$ & $\begin{array}{c}0.70 \\
(6)\end{array}$ & $\begin{array}{c}0.54 \\
(4)\end{array}$ & $\begin{array}{c}0.63 \\
(0)\end{array}$ & $\begin{array}{c}0.63 \\
(6)\end{array}$ & $\begin{array}{c}0.61 \\
(0)\end{array}$ \\
\hline & & $\begin{array}{c}\text { Compressive } \\
(\mathrm{COV}(\%))\end{array}$ & $\begin{array}{c}0.63 \\
(6) \\
\end{array}$ & $\begin{array}{c}0.59 \\
(5)\end{array}$ & $\begin{array}{l}0.68 \\
(15) \\
\end{array}$ & $\begin{array}{c}0.68 \\
(4) \\
\end{array}$ & $\begin{array}{c}0.66 \\
(6)\end{array}$ \\
\hline & & $\begin{array}{l}\text { Modulus of Elasticity } \\
(\operatorname{COV}(\%))\end{array}$ & $\begin{array}{c}181.47 \\
(5)\end{array}$ & $\begin{array}{c}136.73 \\
(16)\end{array}$ & $\begin{array}{c}175.46 \\
(30)\end{array}$ & $\begin{array}{c}107.71 \\
(11)\end{array}$ & $\begin{array}{c}93.08 \\
(28)\end{array}$ \\
\hline \multirow{3}{*}{$\begin{array}{l}\text { LC31 } \\
(25 \%)\end{array}$} & \multirow{3}{*}{$3-1-12$} & $\begin{array}{c}\text { Flexural } \\
(\operatorname{COV}(\%))\end{array}$ & $\begin{array}{c}1.13 \\
(6)\end{array}$ & $\begin{array}{l}1.27 \\
(10)\end{array}$ & $\begin{array}{c}1.13 \\
(9)\end{array}$ & $\begin{array}{l}1.06 \\
(14)\end{array}$ & $\begin{array}{l}1.16 \\
(13)\end{array}$ \\
\hline & & $\begin{array}{l}\text { Compressive } \\
(\mathrm{COV}(\%))\end{array}$ & $\begin{array}{c}1.88 \\
(5)\end{array}$ & $\begin{array}{l}1.65 \\
(25)\end{array}$ & $\begin{array}{l}2.86 \\
(14)\end{array}$ & $\begin{array}{l}2.26 \\
(14)\end{array}$ & $\begin{array}{c}2.57 \\
(5)\end{array}$ \\
\hline & & $\begin{array}{l}\text { Modulus of Elasticity } \\
(\mathrm{COV}(\%))\end{array}$ & $\begin{array}{l}382.75 \\
(6)\end{array}$ & $\begin{array}{c}382.53 \\
(18)\end{array}$ & $\begin{array}{l}487.68 \\
(6)\end{array}$ & $\begin{array}{l}443.32 \\
(6)\end{array}$ & $\begin{array}{l}416.10 \\
(14)\end{array}$ \\
\hline \multirow{3}{*}{$\begin{array}{l}\text { LC21 } \\
(33 \%)\end{array}$} & \multirow{3}{*}{$2-1-9$} & $\begin{array}{c}\text { Flexural } \\
(\mathrm{COV}(\%))\end{array}$ & $\begin{array}{c}1.52 \\
(5)\end{array}$ & $\begin{array}{l}1.27 \\
(15)\end{array}$ & $\begin{array}{c}1.52 \\
(5)\end{array}$ & $\begin{array}{c}1.60 \\
(3)\end{array}$ & $\begin{array}{c}1.29 \\
(4)\end{array}$ \\
\hline & & $\begin{array}{c}\text { Compressive } \\
(\mathrm{COV}(\%))\end{array}$ & $\begin{array}{c}2.64 \\
(9)\end{array}$ & $\begin{array}{r}2.33 \\
(16)\end{array}$ & $\begin{array}{l}2.53 \\
(12)\end{array}$ & $\begin{array}{c}3.76 \\
(6)\end{array}$ & $\begin{array}{l}3.10 \\
(14)\end{array}$ \\
\hline & & $\begin{array}{l}\text { Modulus of Elasticity } \\
(\operatorname{COV}(\%))\end{array}$ & $\begin{array}{c}405.02 \\
(9) \\
\end{array}$ & $\begin{array}{c}481.46 \\
(9)\end{array}$ & $\begin{array}{c}524.15 \\
(12)\end{array}$ & $\begin{array}{c}528.21 \\
(3)\end{array}$ & $\begin{array}{c}476.86 \\
(6) \\
\end{array}$ \\
\hline \multirow{3}{*}{$\begin{array}{l}\text { LC11 } \\
(50 \%)\end{array}$} & \multirow{3}{*}{$1-1-6$} & $\begin{array}{c}\text { Flexural } \\
(\mathrm{COV}(\%))\end{array}$ & $\begin{array}{l}2.57 \\
(24)\end{array}$ & $\begin{array}{c}2.92 \\
(3)\end{array}$ & $\begin{array}{c}2.91 \\
(4)\end{array}$ & $\begin{array}{c}2.71 \\
(5)\end{array}$ & $\begin{array}{l}2.84 \\
(12)\end{array}$ \\
\hline & & $\begin{array}{l}\text { Compressive } \\
(\operatorname{COV}(\%))\end{array}$ & $\begin{array}{c}5.83 \\
(6)\end{array}$ & $\begin{array}{l}5.27 \\
(11)\end{array}$ & $\begin{array}{l}8.21 \\
(17)\end{array}$ & $\begin{array}{c}6.36 \\
(4)\end{array}$ & $\begin{array}{l}8.58 \\
(4)\end{array}$ \\
\hline & & $\begin{array}{l}\text { Modulus of Elasticity } \\
(\operatorname{COV}(\%))\end{array}$ & $\begin{array}{c}631.89 \\
(2)\end{array}$ & $\begin{array}{c}604.78 \\
(6)\end{array}$ & $\begin{array}{c}671.51 \\
(5)\end{array}$ & $\begin{array}{c}627.62 \\
(2)\end{array}$ & $\begin{array}{c}683.58 \\
(1)\end{array}$ \\
\hline \multirow{3}{*}{$\begin{array}{c}\mathrm{LC} 12 \\
(66 \%)\end{array}$} & \multirow{3}{*}{$1-2-9$} & $\begin{array}{c}\text { Flexural } \\
(\mathrm{COV}(\%))\end{array}$ & $\begin{array}{c}4.12 \\
(9)\end{array}$ & $\begin{array}{l}3.71 \\
(13)\end{array}$ & $\begin{array}{c}4.14 \\
(8)\end{array}$ & $\begin{array}{c}3.83 \\
(3)\end{array}$ & $\begin{array}{c}4.23 \\
(2)\end{array}$ \\
\hline & & $\begin{array}{c}\text { Compressive } \\
(\mathrm{COV}(\%))\end{array}$ & $\begin{array}{c}8.24 \\
(4)\end{array}$ & $\begin{array}{c}9.45 \\
(7)\end{array}$ & $\begin{array}{c}10.45 \\
(4)\end{array}$ & $\begin{array}{c}11.34 \\
(8)\end{array}$ & $\begin{array}{c}10.52 \\
(5)\end{array}$ \\
\hline & & $\begin{array}{l}\text { Modulus of Elasticity } \\
(\operatorname{COV}(\%))\end{array}$ & $\begin{array}{l}633.61 \\
(5)\end{array}$ & $\begin{array}{c}701.02 \\
(1)\end{array}$ & $\begin{array}{l}691.50 \\
\text { (3) }\end{array}$ & $\begin{array}{l}719.96 \\
\text { (2) }\end{array}$ & $\begin{array}{l}681.81 \\
(2)\end{array}$ \\
\hline \multirow{3}{*}{$\begin{array}{l}\text { LC13 } \\
(75 \%)\end{array}$} & \multirow{3}{*}{$1-3-12$} & $\begin{array}{c}\text { Flexural } \\
(\mathrm{COV}(\%))\end{array}$ & $\begin{array}{c}3.47 \\
(5)\end{array}$ & $\begin{array}{l}3.56 \\
(15)\end{array}$ & $\begin{array}{c}4.40 \\
(0)\end{array}$ & $\begin{array}{l}3.74 \\
(11)\end{array}$ & $\begin{array}{c}4.01 \\
(1)\end{array}$ \\
\hline & & $\begin{array}{c}\text { Compressive } \\
(\mathrm{COV}(\%))\end{array}$ & $\begin{array}{c}9.17 \\
(9) \\
\end{array}$ & $\begin{array}{c}9.19 \\
(4) \\
\end{array}$ & $\begin{array}{c}12.85 \\
(11) \\
\end{array}$ & $\begin{array}{c}9.38 \\
(6) \\
\end{array}$ & $\begin{array}{c}12.34 \\
(5) \\
\end{array}$ \\
\hline & & $\begin{array}{l}\text { Modulus of Elasticity } \\
(\operatorname{COV}(\%))\end{array}$ & $\begin{array}{l}685.49 \\
(2)\end{array}$ & $\begin{array}{l}698.41 \\
(3)\end{array}$ & $\begin{array}{c}780.83 \\
\text { (2) }\end{array}$ & $\begin{array}{c}683.30 \\
(3)\end{array}$ & $\begin{array}{l}717.74 \\
\text { (3) }\end{array}$ \\
\hline
\end{tabular}

